\title{
Homelessness and Exclusion: Regulating public space in European Cities
}

\author{
Joe Doherty, Volker Busch-Geertsema, Vita Karpuskiene, Jukka \\ Korhonen, Eoin O'Sullivan, Ingrid Sahlin, Antonio Tosi, Agostino \\ Petrillo and Julia Wygnańska1
}

\begin{abstract}
Public space is an essential component of the daily life of homeless people, whether rough sleepers or hostel dwellers or others who are inadequately housed. During 2006 a group of researchers from the European Observatory on Homelessness ${ }^{2}$ considered the ways in which the increasing surveillance, regulation and control over public space, evident in all European cities, has impacted on the lives of homeless people. In this paper we chart the background to this latest phase in the 'regulation of urban space' and assemble evidence from across Europe and especially from our case study countries - Finland, Germany, Ireland, Italy, Lithuania, Poland, and Sweden. We attempt an analysis of these trends using concepts of 'border control', 'discipline' and 'deterrence'. We also consider a limited number of examples of resistance by and on behalf of homeless people to the imposition of restrictions on public space access. In the concluding section, we reflect on related wider societal processes associated with urban regulation and surveillance and their impact on the use of public space.
\end{abstract}

\section{Introduction: the regulation and surveillance of public space}

Over the past decade or so, an emerging trend in the cities of Europe and North America has been the increased regulation of public space and the surveillance of its inhabitants. The present phase of regulating public space, at least in the cities of Europe, is but the latest manifestation of a trend which can be traced back through the $20^{\text {th }}$ to the $19^{\text {th }}$ century and beyond. Indeed we can identify a (weak) link with the processes of enclosure of common land in Europe during the $18^{\text {th }}$ and $19^{\text {th }}$ century and earlier; a process which turned much hitherto community owned and commonly used land into private ownership and exclusive use. With the emergence of industrial urbanism the process of 'privatisation' continued and extended to the burgeoning towns and cities as land was coopted for industrial production and for exclusive residential use - gated communities have their origin in the $19^{\text {th }}$ century city and indeed can be tracked back to the walled and

\footnotetext{
${ }^{1}$ Correspondence: Joe Doherty, Centre for Housing Research, School of Geography and Geosciences, University of St. Andrews, UK. mailto:jd@st-andrews.ac.uk

${ }^{2}$ The European Observatory on Homelessness is the research 'arm' of FEANTSA http://www.feantsa.org/
} 
enclaved cities of the Middle Ages (Blakely and Snyder, 1997). The increasing strength of metropolitan governments from the late $19^{\text {th }}$ century through first three quarters of the $20^{\text {th }}$ century saw the zoning of land for various dedicated uses, much designated sometimes by default - as land and property for public access (streets, parks, libraries, museums, squares, etc.).

A new 'phase of regulation' (O'Sullivan, 2006; Body-Gendrot, 2000) of public space emerged with the shift from the 'planned' city to the 'entrepreneurial' city (Hall, 2002) or to what others have labelled the 'post industrial' city - during the last quarter of the $20^{\text {th }}$ century. The re-designation or re-defining (Sahlin, 2006) of 'public' space as 'private' or 'semi-private' or 'quasi-public' can be seen as part of a more general privatisation of the public realm. The present phase of regulation is characterised to an unprecedented degree by surveillance effected through the use of monitoring devices such as CCTV as well as by the patrolling of demarcated borders by security personnel designed to deter access by unwanted 'others' (Graham and Marvin, 2001).

Control over access is also accomplished by the disciplining of behaviour; that is, access is assured only to those who engage in permitted behaviours which, increasingly, are associated with consumption activities. The use of national legislation and local by-laws figure strongly but unevenly in this process. The intensity with which these controls on access to public space are exercised varies significantly from place to place. As McCahill (2002: 200) observes, the way 'new surveillance technologies', 'new modes of governance' and 'exclusionary practices' are applied in practice 'depends upon how they fit in with existing social relations, political practices and cultural traditions in different locales and institutional settings.'

To explore these issues, we look at the evidence from across Europe and especially from our case study countries - Finland, Germany, Ireland, Italy, Lithuania, Poland, and Sweden. There are copious examples of public space restrictions operating through a variety of surveillance mechanisms which (with genuflections in the direction of Foucault) we consider under the headings of 'border control and discipline' and 'deterrence'. We also consider the issue of legislation as it relates to the restrictive use of pubic space by marginal populations. In the final substantive section of the paper we reflect on the limited examples of resistance to the imposition of restrictions in various contexts and conclude with a consideration of a range of explanations for the present-day imposition of restricted access.

The empirical focus of this paper is on what Meert et al (2006), following Carmona et al (2003), call quasi-public spaces; that is spaces 'that are legally private but are a part of the public domain, such as shopping malls, campuses, sports grounds and ... privatised transport facilities' (p.3). Many of the trends apparent in quasi-public spaces are, however, also apparent in what Meert and his colleagues label 'external public spaces' squares, streets and parks. Quasi-public spaces though privately owned are theoretically accessible to all. While everyone supposedly has the right of admittance, access can be and is denied when a person is judged to have violated specific 'rules and regulations' relating to actual or suspect behaviours. The recent significant increase in the number of quasi-public spaces in the cities of Europe has had - as Jeremy Waldron (1993), among others (e.g. Mitchell, 2003; Bromley, 2006), has argued - important implications for 
homeless people. Human beings, as embodied entities, need a private and secure location in which to carry out necessary and quotidian functions such as sleeping, washing, reproducing and socialising. In advanced industrial democracies, such a location is typically secured by access to housing. Homeless people by definition are unable to access adequate housing of their own, and societal property rules forbid access (without permission) to the private property (houses) of others. The alternative location for homeless people, ${ }^{3}$ for human functioning, is public space (broadly defined).

Access to public space ${ }^{4}$ for homeless people is increasingly under threat as city authorities and some national governments impose restrictions on access for certain categories of people. However, as our evidence demonstrates, while legislation is sometimes enacted with homeless people in mind, the homeless are infrequently the explicit target; nevertheless the impact is disproportionately felt by homeless people because of their reliance on public space for conducting their day-to-day activities. Restricted access to public space for homeless people is then rarely absolute, more commonly it is conditional, for example, on time of day or intended activity. In contrast to previous phases of regulation, in the present phase it can be argued - but perhaps not pushed too far - that the mechanisms of enforcement adopt a 'soft' rather than a 'heavy handed' approach and their raison d'être is couched in the 'reasonable' language of the wider social good, rather than vested interests or personal benefit.

While it is clear that limitations and restrictions on access to public space are a common feature of all European societies, the extent and depth of this process varies from place to place (Tosi \& Petrillo, 2006; Wacquant, 2001). Part of this variation is attributable to different traditions and attitudes towards marginal groups and perhaps especially towards homeless people. In Germany prohibitions against begging are regarded as 'unconstitutional' and 'legally invalid' in that such restrictions would 'violate the free development of one's personality', a principle enshrined in the German constitution (Nagel, 2007:13). In Lithuania giving to the poor on the streets and responding to the entreaties of beggars is seen as a positive, charitable, socially acceptable act (Karpuskiene, 2006), and in Italy a solidarity paradigm of shared responsibility is also frequently apparent in this context (Tosi and Petrillo, 2006). In contrast, in other countries such as Finland (Korhonen, 2006) such 'charitable' actions are less well entrenched as acceptable behaviour and, in some (e.g. the UK) are actively discouraged by government authorities. ${ }^{5}$ Such variation in behaviour and attitudes may however be a waning characteristic, an historical relict, with behavioural norms converging as clampdowns on 'undesirable' people and 'anti-social' practices become commonplace across the continent.

\footnotetext{
${ }^{3}$ Homelessness is a contested concept, but in this context it is sufficient to state that homeless people lack private space.

'In the following, we use the short-hand label 'public space' to encompass reference to both' quasi' and 'external' public space.

5 e.g. The 'Killing by Kindness' campaign in the London boroughs of Westminster and Camden http://www.westminster.gov.uk/councilgovernmentanddemocracy/councils/pressoffice/news/archive/pr2370.cfm
} 
Certainly what seems to be clear is that the process in Europe is less punitive and less pervasive than in the USA. An example of the difference is to be found in the reluctance to adopt hard-line zero-tolerance police methods in European cities compared with their ready adoption in some larger American cites (Body-Gendrot, 2000, Chapter 5; Wacquant, 1999). Additionally, as Low and Smith argue, the clamp down on the use of and access to public space in the USA is driven much more conspicuously, since $9 / 11$, by a 'terrorist' agenda:

From city park[s] to public streets, [from] cable and network news shows to internet blog sites, the clamp down on public space in the name of enforcing public safety and homeland security has been dramatic. Public behaviour once seen simply as eccentric or even protected by First Amendment rights is now routinely treated as a potential terrorist threat. (Low and Smith, 2006: 1-2)

While the terrorist threat is not generally an overt driving force of present restrictions in Europe (though see Whent, 1999), the notion of 'security' in a more general sense is frequently invoked by city governments and other agencies as justification for the implementation of restrictions on the use of public space. 'Security' in this context incorporates both notions of 'safety' - freedom from the fear of crime etc. - and, in these 'terrorist alert times', further meanings that play on people's fears of 'terrorism' which can be influential in acquiring public acquiescence to restrictive practices (Bannister and Fyfe, 2001; Oc and Tiesdell, 1997; van den Berg et al, 2006). In this sense, and in the sense that such measures are only rarely linked overtly to issues of terrorism, it can be argued that the present phase of regulation in Europe has a distinctive ideology separating it from past phases and from similar developments in the USA.

\section{The regulation of space: evidence from the case studies}

Drawing together evidence of public space regulation from our seven case study countries - Sweden, Poland, Lithuania, Italy, Ireland Germany and Finland - we consider several mechanisms of surveillance and control under the headings: (i) 'border control and discipline', (ii) 'deterrence' and (iii) 'legislation'. It is our contention that the practice of surveillance and control of public spaces by patrolling border guards in combination with the deployment of 'panoptic' monitoring by technological devices, operate to 'socially sort' (see Lyon, 2003) and 'exclude' homeless people and others who do not adhere to normative 'rules of engagement'. The process of exclusion is further promoted by an assortment of deterrence devices linked to the spatial arrangement of public space particularly in the deployment of architectural infrastructure. These 'mechanisms' for sorting, excluding and deterring are grounded in a matrix of punitive rules enacted through national and regional legislation, local by-laws and more loosely defined locality regulations.

\section{Border control and disc ipline}

Ingrid Sahlin (2006) articulates the concepts of border control and discipline following a consideration of Foucault's (1977) work on prisons which draws on an historical analysis 
of the combating of disease in medieval cities, specifically the handling of lepers and the outbreaks of the plague in the later middle ages. Foucault identified two processes: the rejection and expulsion of problem people in order to keep the medieval town 'clean', and the spatial organisation and control of inhabitants to suppress the plague epidemic. For Foucault, the latter system is an analogy for discipline, the form of control that includes the supervision and training of 'deviants' in appropriate modes of behaviour acceptable to the community which was first developed in the $19^{\text {th }}$ century prisons and later spread to other social arenas such as schools, work places and housing (see also Arnold, 2004, Chapter 4; Elden, 2003; Bratlinger \& Ulin, 1993;). Sahlin notes that the same strategies can be identified in the modern city as a means of keeping order: private guards and gatekeepers survey the borders of delimited territory to keep unwanted people out, while police and security personnel use discipline to keep order in public spaces, where crude expulsion is in principle often illegal. A key feature here is the way in which, once identified as 'for the common-good', many of these surveillance and control mechanisms are accepted and uncontested by individuals and communities, who themselves become active in their enforcement (Fopp, 2002).

Central to the process of controlling public space is the designation of borders (boundaries). In this context the notion of 'redefinition' is important. The attribution of labels - 'public' vs. 'private'; 'semi private' vs. 'quasi public' - is clearly of considerable significance in shaping 'legitimate' uses of space and rules of access. An example from Sweden is Nordstan: a huge shopping mall covering eight city blocks in the centre of Gothenburg. Originally, Nordstan was an area of mixed land use whose streets were accessible as public space to all city inhabitants and visitors. Located close to the central bus and railway station these streets served as major access routes for travellers and commuters. Redevelopment resulted in the demolition of existing buildings and their replacement with a variety of new commercial activities; the original street pattern was retained and enclosed with the addition of a glass roof. With redevelopment and enclosure came calls for restricted access. Nordstan's position close to Gothenburg's central transport nodes meant that the centre was populated not just by shoppers but also by a large number of non-consumers. Accordingly, Nordstan was viewed as not only a commercial centre but also as a public place where people gathered - these people included the young, substance misusers and homeless people. The congregation of these marginal groups - in contrast to the congregation of shoppers and travellers - was frequently construed as a social problem leading to increasingly clamorous and eventually successful calls for restrictions on access. The events are recounted by Sahlin:

In $\ldots$ the middle of the $1990 \mathrm{~s}$, the 'problem of order' in Nordstan was framed as a 'youth problem', and social workers and politicians from the Christian Democratic Party expressed worries that teenagers in Nordstan risked becoming criminals and drug addicts. Ten years ago, a motion was submitted to the City Parliament on the need for coordinated activities by the police, other authorities, businessmen, and property owners to improve public order in Nordstan. Locking the entire centre at night was mentioned as a possible solution but rejected by the politicians who [nevertheless] agreed that the city should cooperate with business and property owners for improved order. (Sahlin, 2006:19) 
Following this rejection by the city's politicians, property owners and tenants (that is, shops and restaurants with businesses in Nordstan) formed an 'Order Group', which aimed at improving the reputation and profitability of the shopping centre. The 'Order Group' arranged a series of meetings with the police, other public authorities and charity organisations demanding that Nordstan be prioritised for resource allocation and the police should enforce prohibitions against drinking within the Centre. Furthermore, the group declared its intention to employ security guards and contracted a lawyer to examine the legal possibilities of closing the centre at night as well as increasing video surveillance (Sahlin 2006: 19-20).

From October 2004 the Nordstan Centre has been locked and barred to the public between 0200 hours and 0530 hours. The formal reason for the closure is to facilitate cleaning and repair and to make it easier to organise exhibitions. However, preceding the enforcement of night closure, there was a clamp down on 'undesirables' by police and private security guards (introduced in 2000) which especially impacted on homeless people who might be tempted to use the enclosed space of the Centre for night shelter. The extent of the intervention is also demonstrated in the removal of benches and partitions: there is nowhere to rest or hide from the gaze of the video surveillance.

Elsewhere in Europe similar developments to those identified in Gothenburg are apparent, especially in association with major transport nodes. David Giannoni (2007), for example, identifies the ways in which 'an increasingly coercive security approach' has been adopted in an attempt to control the use of public space in the Brussels South train station. He notes the importance of such public places as places of congregation for homeless people in that they provide economic possibilities (for begging and sometimes stealing), as well as a meeting place for the exchange of information and socialising. In addition they are seen as places of safety (violence is a daily threat to homeless people) and as places of shelter from inclement weather. They also provide access to toilets and drinking water and sometimes provide a source of sustenance in the form of left-overs from food retailers. Brussels South is one of the main international arteries for rail travel in Europe and the main railway station in Brussels; it is the Belgian Terminus for Eurostar and Thalys. As such it is a 'window' on Belgian and Brussels society (Giannoni, 2007:9); its image and security have increasingly been a cause of concern for politicians and commercial interests. In pursuit of an improved image, use of the station has become increasingly restrictive with undesirable and marginal populations (i.e. those who are neither travelling nor consuming) targeted for exclusion. In pursuit of these aims the private security guards (the so called 'Bsecurity'), employed by the commercial interests of the station, have resorted to crude and sometimes violent methods of extraction which have disproportionably affected homeless groups. That these surveillance and policing activities have been effective is demonstrated by the 'peripheralisation' of homeless people to the edges of South Station, 'to the side entrances, out of range of the commercial activity of the traders in the station' (Meert et al, 2006: 24).

In Germany as part of an ambitious programme of modernisation of the Deutsche Bahn designed to increase profitability prior to privatisation - railway stations have been redeveloped with shopping centres enhancing their functional diversification. BuschGeertsema (2006) recounts that: 
[i]n the late 1990s it was planned to convert about half of the more than 6,000 existing railway stations into modern centres for shopping and service by investing about 15 billion Euro ... Cologne, Frankfurt, Hamburg, Hanover, Mannheim, Leipzig and the new main station in Berlin are only a few examples [of] where this strategy [has been] realised. Shopping areas in the new railway stations are particularly attractive for business because their opening hours are exempt from the usual restrictions which are imposed elsewhere in Germany, and because of the location which ensures that large numbers of potential clients pass by. The new main railway station in Berlin, opened in 2006, provides 15,000 square meters of space for 80 shops, open 7 days a week until 22.00 or later; Leipzig main station ... provides 30,000 square meters [for] 140 shops, including food shops and restaurants ... (Busch-Geertsema, 2006: 15)

The '3-S-program' (Service, Sicherheit und Sauberkeit - service, security and cleanliness) is the sound-bite label which encapsulates the strategy of Deutsche Bahn to improve the image of its stations. Universal rules imposed in every station forbid begging and the causing of a nuisance to others, the excessive consumption of alcohol, sitting or lying on floors, stairs and entrance areas, and the searching garbage bins. Busch-Geertsema continues his account:

In 54 so called " 3 -S-centres", 27 of which are equipped with modern video and communication equipment, the new standards are imposed. According to recent press information ... the numbers of people working in security services at the railway stations will be increased from 2,200 to 3,000 persons $\ldots$ In addition about 5,000 members of the national police guard (former Bundesgrenzschutz) are present in German railway stations. (2006: 11)

In contrast to the Swedish case of Nordstan, the German railway authorities have not been reluctant to explicitly identify the target of their rules. Homeless and poor people, who have traditionally been present in large numbers in and around German railway stations, are not welcome under the new strategy and the removal of homeless people and of substance misusers from stations has been an overt target of the Bahn-management.

In 2001 the railway chief, Hartmut Mehdorn, stated ... that 'railway stations are not the right place for homeless people' and called on the Travellers' Aid Centres (Bahnhofsmision) to stop handing out hot meals to homeless people. 'If it rains and the Bahnhofsmission provides soup, no homeless [person] is prepared to go out into the rain. They sit down at the entrance and ask for some change. Our clients don't like that. Homeless people are not malicious people, but they don't fit into the railway station'. (Bild am Sonntag, 14.10.01; quoted in Busch-Geertsema, 2006:12)

There is a certain irony here in that the extension of the function of railway stations to incorporate shopping has on the one hand underlined and emphasised their public character and the fact that they are not only used by travellers. Yet on the other hand, only sections of the public are welcome, that is those who conform to the rules of 
engagement in shopping or travelling. The use of this public space is not available to all (see also Eick, 2003). Busch-Geertsema concludes, "the main shift in the orientation of the Bahn-management has been from citizens to business clients, and a shift away from acknowledging the traditional social functions of railway stations for certain groups [in] society." (2006: 12)

Tosi and Petrillo's account of railway developments in Italy conveys a similar message. They explicitly link the changes in railway terminuses in Italy with issues of regeneration of ancient stock in need of repair and replacement, a process reflected in a shift in ownership from the state to private enterprise:

In Italy the project Grandi Stazioni ('Great Stations') got under way in 2003 and involved the modernisation of thirteen large stations and the surrounding areas in the space of a few years. More specifically the project ... involve[s] ... architectural, urban and social redevelopment as well as enhancing the business environment of 13 stations in the country's major cities. Another project, named Centostazioni ('Hundred Stations'), [will] involve another 103 Italian railway stations. (Tosi \& Petrillo, 2006: 10)

The introduction of commercial activity implies that stations would of necessity lose some of their traditional functions in that their hitherto clear designation as public spaces becomes clouded as they take on the characteristics of 'semi-public' or even 'private' places where business arcades and shopping centres vie with travel as the dominant function. For Tosi and Petrillo the consequences are broad ranging:

...not only will the public spaces inside stations be affected by the changes in progress but also those immediately adjacent to them. If one considers that stations - and not just the large stations, but also those of the 'hundred towns' of medium to small size - have played an extremely important role historically for ... the homeless and the seriously marginalis[ed], then it is clear that this type of change will have a serious effect on the life of these populations... Stations in Italy act as gateway[s] for access to the networks of resources that are available to the poor in urban environments. They represent indispensable places to stop and linger and they are also places where it is possible to earn tiny incomes from begging, to scavenge something edible, to use the public conveniences and gain access to water. The expulsion, removal and forced re-accommodation of the homeless risks becoming a catastrophe for them precisely because it is not just a place to pass the night that is lost, but an entire network of extremely varied opportunities which are concentrated in an extremely circumscribed place. (Tosi \& Petrillo, 2006:10)

In their evaluation of the importance of Italian stations as places of interaction for homeless and other socially marginal groups, Tosi and Petrillo echo some of the earlier reflections of Hopper (2003) in his assessment of the role of airports in the USA. Hopper notes that in such public spaces more flexible standards of behaviour are frequently witnessed: 
The $[\mathrm{m}]$ ost striking cultural distinction of the airport is the degree to which some accepted canons of social behaviour - especially those having to do with the segregation of private and public spheres of life - are conditionally suspended...in this limited sense, the airport ....may be seen as a kind of 'liminal' space, ... [a] self-contained space of happenstance and strangers [where] a casual and improvised attitude towards the presentation of self ...seems to obtain. (Hopper, 2003:123)

For Tosi and Petrillo, in depicting stations acting as 'inner borders' subjected to careful surveillance, it is precisely this flexibility of behaviour that is being targeted and stifled. The heightening of surveillance has meant that it is impossible for a whole range of marginal populations to use the space of stations in the traditional way.

Tosi and Petrillo also observe that while security concerns may be responsible for recent increases in surveillance, restrictive measures designed to discourage the use of stations by homeless people and immigrants were introduced as far back as 1996; that is, preceding the eruption of urban terrorism in Madrid in 2004 and in London in 2005. These measures included the possession of a valid ticket for access to waiting rooms and platforms and, in large stations, the introduction of charges for the use of public conveniences which are monitored by security personnel (cf. Damon, 2007, for an account of similar developments in France). In smaller stations, public conveniences are routinely locked and only useable on direct request. However, until the advent of more rigorous surveillance in the form of CCTV cameras, it was relatively easy for some homeless people to find shelter in particular parts of stations and in some cases even in carriages parked in railway sidings (Tosi \& Petrillo, 2006: 10).

Tosi and Petrillo usefully link these demarcation in the use of public space to wider trends in the in the cities of Europe and elsewhere. They argue that,

' $[\mathrm{t}]$ here is a new need for transparency in spatial units which perform delicate functions, which is exactly what stations do. That is why parts of cities which perform vital functions and present 'unclear' uses and which have multiple functions that go beyond their main ... role are being progressively enclosed and subject to more careful controls. (Tosi \& Petrillo, 2006:11)

The Italian experience with the 'redesignation' of stations includes some distinctive features absent (or less developed) elsewhere in Europe. In drawing up the Italian 'Great Stations' project, an awareness was demonstrated on the part of the enforcing authorities of the social implications of the planned redevelopment. For example, the slogan 'quality, market, social' (cf. the 'service, security and cleanliness' associated with the German Deutsche Bahn redevelopment) was used in promoting the project; the term 'social' underlining an intention not to intervene too harshly with regard to homeless and other marginal populations that use stations. In pursuing this objective, the State Railways have begun to develop links with local authorities and voluntary associations to cater for those displaced by the 'modernisation' process. An agreement signed in June 2005 between the State Railways and A.N.C.I. (National Association of the Municipalities of Italy) established a common strategy of intervention at the national level to deal with the 
problems of social hardship in railway stations. 'Help Centres' have been set up (or are being set up) in major Italian stations with the assistance of local authorities. In a parallel move, 'Ferrohotels', previously used for railway workers and long empty, are being brought back into service as accommodation for homeless people. However, in Tosi and Petrillo's judgement, the functioning of the 'Help Centres' has so far been questionable, even in the few situations in which they have actually been established. The Help Centre in Rome is possibly an exception in that it is the only Centre actually located inside a railway station complex. It has been effective from a social viewpoint, although without completely eliminating the presence of marginal populations. Tosi and Petrillo conclude:

Generally speaking it can be said that the removal of a part of the homeless and the marginal populations from Italian stations has been achieved as a consequence of these interventions, even if performed with a 'soft' touch. ... [the number of homeless people in railways stations] reported by welfare organisations is decreasing almost everywhere and this tendency is strongest in cities like Milan. (Tosi \& Petrillo, 2006:12)

The important caveat in the foregoing quotation is the phrase 'part of the homeless'. While the numbers have reduced, homeless people and other groups which make up Italy's marginalised population (e.g. immigrants and Roma) are still to be found inside stations. Marginalised populations may be rarer that they once were, 'but there are still gaps ... in which vagrants with big bags and homeless people trying to warm themselves can find some shelter for a certain time (but not for too long!)' (Tosi \& Petrillo, 2006:13). The evidence from some of the other case studies which form the empirical basis for this paper, namely Finland, Poland and Lithuania, reinforces the foregoing message. Across Europe transport nodes, which act as centres for homeless people to perform their quotidian functions, are increasingly difficult to access. Increased monitoring and surveillance, which control both right of entry and conduct (Müller and Boos, 2004), ensure that even if achieved, access is often limited and short lived. In the case of Poland for instance, Julia Wygnańska (2006) recounts recent developments at the Central railway station in Warsaw. Though the location for some kiosks and small shopping outlets, the principal activity of Warsaw Central is as a conduit for internal and international rail travel, yet even here - without the immediate impress of commercialisation so conspicuous in Sweden, German and Italy - the forces of change regarding the regulation of public space have been apparent in recent years. As with railway and bus stations throughout most of Europe, Warsaw station has traditionally been the haunt of homeless people and beggars. Under new regulations the security forces that patrol the railway station - the national police, community police and the Railway Protection Service - are obliged to remove homeless people from the station during the night when there are no rail services and when cleaning is scheduled. At other times they have an obligation to inform homeless people about the availability of shelter services in town and encourage them to move there. The interaction between homeless people and security staff is contentious with the homeless citing instances of aggressive behaviour and the railway authorities claiming that aggressive actions are directed only towards drunk and abusive individuals. Wygnańska observes that homeless people,

...used to be seen everywhere: among passengers, in restaurants, on the platforms. Since two years they have moved to more camouflaged places. 
According to [the] press officer of Polish Railway Company [this] is the result of increased monitoring of the stations by police patrols [initiated] by [the] general threat of terrorism and is not directly targeted at the homeless. (Wygnańska, 2006:11-12)

In the context of the use of public space the the self-regulation dimension of Foucault's concept of 'discipline' is more difficult to evidence. The survey of homeless people in seven EU countries by Henk Meert and colleagues (Meert, et al 2006), however, indicates that homeless people do monitor and, in obvious ways, alter their own behaviour as a consequence of surveillance: reducing visibility in public places where they are certain to be observed, harassed and excluded and confining themselves to liminal spaces - the edges, the dark corners and the hidden recesses. Another form of 'self-regulation' has been reported by Helms (2007: 293) in France and Germany where long-term unemployed (and almost certainly intermittently homeless) people have been recruited 'as additions to established police agencies'. In Germany, voluntary sector agencies have 'begun to take part in policing activities through training-for-work schemes' and in France through an initiative of the Ministry for Social and Inner Security 'young unemployed people have, through a range of intermediary organizations, become employed as assistant security personnel on public transport ... and as wardens to monitor public spaces'.

As suggested earlier, the enclaved public spaces of the modern city can be seen as an historic continuation of features long apparent in the urban centres of Europe and elsewhere (see, for example, Mitchell, 2003, Chapter 4). What marks out the present, from even the recent past, is not so much the principle of restricted access, but the systematic and pervasive nature of the surveillance mechanisms which sort and exclude; what Staples (1997) has called the exercise of 'meticulous rituals of power':

... [they are] meticulous because they are methodical, thorough, efficient, precise, and fine-grained; ritualistic because [they are] practiced repeatedly and accepted routinely in an impersonal manner; [they are] powerful because [they] discipline people and have social control effects. (Ericson 1998:1154)

Central to these rituals is the deployment of CCTV cameras, the 'electronic fortification' (Monahan, 2006a) which buttresses traditional surveillance mechanism of security patrols and border checking. The European Urbaneye project (Urbaneye, 2004) which charted the expansion and diffusion of CCTV surveillance across six European capital cities has clearly demonstrated the extent of 'surveillance creep' (Nelkin and Andrews, 2003) over the past three decades. The significant expansion in CCTV in the UK in 1994 - when central government funds were first made available through competitive bids for the local deployment of CCTV in public places - is frequently cited as marking the beginning of the diffusion electronic surveillance technology, albeit unevenly, ${ }^{6}$ across Europe. In the

\footnotetext{
${ }^{6}$ Notwithstanding the widespread adoption of CCTV it is important to recognise the hesitant adoption of CCTV surveillance in several European localities. The Urbaneye survey showed that in 2003 in Denmark, Austria, Norway and Germany there were few or no street cameras and several of these countries continue
} 
UK today it is estimated that there is one camera for every 14 people and that each individual is, on average, caught on camera 300 times in every day (Urbaneye, 2004). While not approaching this level of deployment, France, the Netherlands, Ireland and Italy and Spain have all demonstrated the ready and expanded adoption of CCTV in recent years (Norris et al 2004; 113). The increasing take-up and deployment of CCTV is, however, only one dimension in the growing efficacy of camera surveillance. With the advent of digitised recording and algorithmic-enabled surveillance, the panoptic gaze of CCTV has become more sophisticated (and costly). Digitised recording enhances the facilities for facial recognition and what has been referred to as a 'phenetic urge' in the gathering of geodemographic information for interrogation (Lyon, 2003: 5; Norris, 2003); the 'meticulous rituals' are becoming ever more invasive and comprehensive.

\section{Deterrence}

Surveillance architecture ... is intended to program spaces for certain uses.

(Monahan 2006b: x, and 2006a: 174)

Julia Wygnańska's account of the changes in Warsaw identify another issue other than border control and discipline as a method of controlling and limiting access to public space, namely deterrence. One of the strategies purposefully implemented at Warsaw Central has been the removal of old wooden benches - used by homeless people for resting and sleeping - and their replacement with plastic seats designed to deter such activity. These changes have been introduced as part of a planned 'aestheticization' of the station. The railway station management has expressed satisfaction with the results as the seats are durable, easy to clean and deter long term occupancy by homeless people looking for somewhere to rest.

'Deterrence by design' is a common strategy increasingly employed throughout European cities. The use of fencing to restrict access to delimited spaces, the locking of park gates and the installation of secure door entry systems to debar entrance to apartment block staircases and communal areas are recorded as common occurrences in most European countries (for example see Korhonen (2006) on Finland and Karpuskiene (2006) on Lithuania). Sahlin cites the example of a former open space in Gothenburg which was transformed from a public space with multiple functions including respite for homeless people, into a privatised café space with access limited to café patrons. (See also Damon, 2007, on similar developments in France). These interventions, though pervasive, are however relatively low key compared to more extreme measures, such as 'hot-washing' and 'de-canning' employed in parts of urban America. Deterrence techniques in Europe for the most part take on a rather softer character. Yet, there is substantial European evidence of intermittent aggressive and violent behaviour towards marginal populations including the homeless (see Farrona's 2007 account of the situation in Spain). In both Sweden and Germany, for instance, such interventions include the uplifting and removal of homeless people from central city locations and their dumping on city peripheries (Verbringungsgewahrsam in Germany); while in Italy the violent expulsion of homeless from the railway station at Naples by private security personnel is on record. In this context Tosi and Petrillo (2006) raise concerns about the attitudes and behaviour of

to 'lag behind' in the rush to electronic surveillance (Lomell, 2004; Sætnan et al, 2004; Helten and Fischer, 2004). 
private security agents (a little developed phenomenon in Italy) since they seem to be prone to more aggressive behaviour towards marginal groups than the local and state police. A recent evaluation of the criminalisation of homeless people in Rotterdam records similar developments in that city (Zuidam and Pols, 2007).

As the control measures designed to exclude 'undesirable' populations form public space in European cities take hold, the spaces and places of traditional occupancy by Europe's homeless become increasingly restricted and delimited, imposing further hardship on an already disadvantaged group. It is a somewhat flawed argument that as some public spaces close up others, such as derelict areas of former industrial sites and military installations, become available. In conditions of economic growth and expansion such 'redundant' areas rarely remain vacant for long, being converted into parks and office locations which are subject to discipline and border control in the same way as older sites. Even those areas that do not immediately undergo renovation are commonly fenced and subject to electronic surveillance and security patrols to 'preserve' them in anticipation of future commercialisation.

The installation of 'surveillance architecture' (Monahan, 2006b) - what Davis calls the 'conscious hardening of the city surface' - is designed to make public facilities and space as 'unliveable' as possible for the poor and homeless lest 'the persistence of street people in the vicinity of newly renovated shopping centres and refurbished transport nodes betrays the laboriously constructed image of urban renaissance' (Davis, 1990:232).

\section{Legislation}

The repeal of often long redundant $19^{\text {th }}$ century legislation which criminalised beggars and vagabonds was a feature of most west European societies during the 1960s and 1970s (O'Sullivan, 2007). In Belgium for instance, the act that prohibited vagrancy was repealed in 1993 and replaced by a new law which states that homeless people should now be treated in special reception centres designed to prepare them for reintegration with society. Similarly, in France begging and vagrancy prohibition disappeared from the penal code in 1994, and in Norway begging has been formally legalised since January 2006. In Ireland, the offence of vagrancy was decriminalised in 1988 and the begging was decriminalised in 2007. In central and east European countries Soviet legislation criminalising begging was repealed somewhat later during the course of the early 1990s.

Notwithstanding the repeal of some national punitive legislation, throughout Europe dating from the late 1990s, attempts have been made, often at a local metropolitan level, to reintroduce legislation to deter begging and other activities, such as loitering, frequently associated with homeless people. In Lithuania (where Soviet laws against begging were repealed in 1991) a new penal code was introduced in 2003 which enacted penalties against public disorder, aggressive behaviour, and the possession of drugs. Few of these measures targeted homeless people per se; indeed non-aggressive begging and sleeping in public places is not regarded as illegal in most of the country. Local legislation, however, has introduced local adjustments and refinements. In Vilnius, for example, 38 public places have been designated as alcohol free zones where begging is outlawed. This legislation has been paralleled by the introduction of other surveillance measures: under the banner of 'save the city', police and social worker patrols have been 
introduced and video cameras have been installed in the city centre, located at underground crossings and at train and bus stations. In other punitive moves to deter unwelcome behaviour, garbage dumps have been locked thereby depriving some homeless people of a living through the recycling of discarded goods and waste products. In Slovenia begging is also prohibited by law. According to the new Act on protection of public order and peace, adopted in June 2006, 'anyone found begging for money or other material goods in an intrusive or offensive way' or sleeping in public places that are 'not intended for this purpose and where this causes problems for some other person' can be penalised. And in France, even though begging no longer figures in the penal code, it is still forbidden to beg at the railway stations and on trains (Meert et al, 2006: 4-5).

By and large, however, throughout Europe attempts to introduce legislation that explicitly targets homeless people have been unsuccessful. Indicative of this failure is the fate of experiments with zero-tolerance policing. In Germany, for instance, where non-aggressive begging is perfectly legal, attempts to prosecute homeless people for harassment in the course of begging have been notably ineffective. As Busch-Geertsema notes (2006:6) zero tolerance has found its limits in Germany because of differences (compared with the USA) in constitutional traditions and policy ethos with regard to policing and keeping order. Similarly, in Denmark 'there is a general legal presumption against the surveillance of public space by private bodies, and explicit regulation of the use of photography by the police' and in Norway 'where privacy rights are constitutionally enshrined, there is a strong data protection regime that has explicitly concerned itself with regulating CCTV through licensing' (Norris, et al 2004: 121). In a further example, experimentation with zero-tolerance in central Tampere, Finland in 1999-2000 was discontinued when complaints of unruly behaviour in suburban communities by individuals displaced from the city centre rose dramatically (Korhonen, 2006:11). In Ireland a crack down on begging and public order type offences in the late 1990s, was only tenuously linked with restrictions on homeless behaviour and access to public spaces (O'Sullivan, 2006). Even the rise in begging convictions in the late 1990s was not accompanied by increases in other vagrancy violations, suggesting that homeless people were not particularly targeted. While this period also saw a substantial increase in the Irish prison population, of all prisoners convicted in 2003, only five were committed for begging, and begging may not have been the only offence with which they were charged. In addition, analysis on the progression routes of homeless persons through the courts showed that of the 9,794 individuals who passed through Irish District or Circuit Courts over a six week period in 2003, only 159 (1.6 percent) were identified as homeless (and this was a rather broad definition, including as it did 17 individuals in transitional housing) and charges of begging accounted for only 6 percent of all charges against them. Information on the outcome of cases by charge was only available in 16 cases and imprisonment for begging (with other charges) occurred in only one case (Seymour and Costello, 2005:32-33). Thus, the relatively short-lived attempt to introduce more punitive criminal policies in the form of zero-tolerance policing and an increased use of incarceration was not directed at the homeless per se, but rather that some homeless persons were ensnared within the criminal justice system as part of this broader temporary policy shift (see also O'Sullivan, 2007:3-4).

In the UK proposals in 2003 to criminalise begging - later downgraded to a recordable offence, stored in the National Police Computer with DNA records of those convicted - 
were roundly condemned by homelessness agencies and human rights organisations (see for example, Gosh, 2003). This punitive stance by the UK government towards begging which impacted disproportionately on homeless people (though not all homeless beg, and not all beggars are homeless) was echoed in the attempt by several city authorities across Britain to 'outlaw' begging on the streets of their domains. Westminster's 'killing with kindness' campaign secured the greatest publicity, but among other 'trailblazers' in this context were Camden, Bristol, Brighton and Hove, and Leeds. The 'killing with kindness' campaign argued that giving-in to street beggars' entreaties for cash only worsened their situation in providing resources for alcohol and drugs to the detriment of the beggar's welfare. While the attempts to curtail begging were nominally linked to concerns about the welfare of beggars, in practice, the fate of the beggars seems to have been the least of the worries of the council in that the stated aim of the campaign was, " $[\mathrm{t}] \mathrm{o}$ create a cleaner and safer environment for the general public across Westminster by taking effective action to reduce begging'. (Westminster Council, 2003) Westminster is perhaps the tourist borough of London (the location of Parliament, Westminster Abbey, Buckingham Place, Royal Parks, numerous museums etc); it is clearly in the council's interests, as a part of its governance strategy of 'sustaining an appropriate investment and consumption climate' that begging is removed from its streets.

Among our case study countries 'area bans' as a way of restricting access to defined public spaces seem to be exclusive to Germany. There are of course (inexact) parallels elsewhere in Europe, for example in the 'Anti-Social Behaviour Orders' (ASBOs) of the UK (see Johnsen and Fitzpatrick, 2007). In Germany ad hoc Platzverweis or longer term Aufenthaltsverbot, bans against staying in a defined area for a defined time, have been increasingly used by police since the 1990s; they have been especially associated with areas notorious for drug dealing and have been applied in particular to suspected drug dealers. Nowadays almost all Länder police laws allow such interventions against people whose behaviour is defined as a potential threat to public security and in specific areas which are defined as 'dangerous areas'. While the homeless are not the group most affected by these measures, such area bans are used to control access by homeless people (Busch-Geertsema, 2006).

In respect of legislation which impacts on the behaviour of homeless people and in particular their access to public space, the following summary for Germany applies equally to other countries:

Summing up we can state that there has been a general trend since the late 1980 s to restrict begging and sleeping rough and to ban the [consumption] of alcohol in public space ... The resistance of poor individuals who were targets of police interventions and went to court against it has helped to make clear that a number of by-laws are not compatible with the German constitution and that only particular individual behaviour which constricts the rights of others can be sanctioned. Nevertheless police intervention to remove undesirable individuals or groups from specific areas without having to legally prove the violation of legal rules has increased in recent years. Homeless people are not the main target group but they - especially those who live and sleep on the street - have to suffer under such measures ... In privatised space open to the public, like shopping malls or arcades 
and nowadays also in railway stations ... it is much easier to restrict access for individuals [who] are unwanted by the proprietors. (Busch-Geertsema, 2006:8)

With the increased commodification of public space, all occupants of that space are forced to conform to the 'rules of property'; that is, the law of trespass and violation enshrined in everyday practice - these are the locality regulations which bind all who inhabit quasi-public and external public space (Bromley, 2006).

\section{Resistance}

Restricted access to public space has deprived many marginal groups of spaces to congregate for social interaction and of places where they can claim some degree of personal comfort in keeping (relatively) warm and dry. For Jeremy Waldron (1993) the denial of access to public space impinges particularly on the location rights of homeless people. Because homeless people by definition have no personal or private spaces that they can call their own, denial of access to public space robs them of a location for basic human functioning and thereby, in Waldron's argument, deprives them of the chance for autonomy of action. Their security, safety and individual welfare are threatened, and their sense of dignity and self-respect is compromised. (See also Edgar, Doherty and Meert, 2002, Chapter 2).

While objections to the enclosure of public space have taken many forms, for example in concerns over the aesthetic of mass produced architecture or ethical unease over the increasing materialisation of society, opposition and resistance to the social impact of restrictions on the right to roam - notwithstanding local and low level resistance - have, for the most part, been remarkably muted and rarely successful for more than a short period of time. There are, however, exceptions to the absence of larger scale resistance. Examples are provided by the national campaigns of Germany's BAG Wohnungslosenhilfe, which organised a series of national actions against the exclusion of poor people from public spaces: e.g. the 'Night of the Homeless' in 1993 and the 1998 campaign 'The City belongs to All'. Both campaigns emphasised the right of poor and homeless people to use public spaces and advocated resistance to privatisation and exclusionary regulations (Busch-Geertsema, 2006:8-9; Nagel, 2007).

In contrast to the paucity of national campaigns, examples of local-level resistance abound. One such instance is provided by the case of Brussels South train station where homeless people, who suffered disproportionately at the hands of the private security guards hired by the commercial interests of the Station, were barred from entry and were extracted sometimes with extreme violence from the station spaces. With the aid of sympathetic social workers, the 'Collectif du Midi', a broad collaboration between grassroots organisations, charitable institutions, services for the homeless and homeless people themselves was established (Meert et al, 2006: 24-25). The collective methodically recorded instances of exclusion and expulsion and used this evidence to represent the interest of the homeless population in attempting to preserve their traditional use of the station forecourt. This campaign was successful in that the instances of abuse and use of undue force abated and security personnel had to 'soften' their approach. However, the identification of homeless people as undesirable occupants of the station 
space continues; as Giannoni observes (2007:10) the policy of 'cleaning and repressing' is still in place.

Busch-Geertsema also cites several local campaigns such as that initiated by Hamburgbased NGOs against the introduction of local by-laws banning begging (2006: 9-10). As Nagel reports, the Hamburg Camber of Commerce initiative to ban organised begging by immigrants during the 2006 World Cup was successfully opposed by an opposition group combining the local street paper ('Hinz und Kunzt' - 'Every Tom, Dick and Harry'7), welfare and social services and church representatives and some opposition parties (Nagel, 2007:12). But the local authorities circumvented the opposition through the introduction of traffic law ordinances which prohibited 'organised and commercial begging' by aliens (mostly Bulgarian), thereby linking poverty and immigration despite little or no evidence of organised or criminal activity among this group. ${ }^{8}$ Nagel concludes (perhaps a bit too optimistically) that the Hamburg example demonstrates 'that campaigns by organisations to provide evidence for the interests of homeless and poor people can be successful and can prevent the introduction of measures prohibiting begging even against the interests of politicians and the business world' (Nagel, 2007:13). Nagel however, also importantly observes that this is 'advocacy' politics, infused with a great deal of paternalism; the organisations involved (with the possible exception of the street newspaper) have made little or no effort to engage directly with homeless people to enable them to 'assert and defend their own rights and interests'.

Elsewhere the national case studies that contributed to this paper recount a number of low-key interventions on behalf of homeless people whose access to public space has been threatened or denied. These take various forms. At the level of what we can label 'non-action', there are many instances of the refusal of courts to criminalise homelessness per se and even reluctance to prosecute homeless people for illegal travel or begging activities. O'Sullivan (2006), for example, is clear that the clamp down on begging and anti-social behaviour in Ireland during the 1990s did not disproportionally impact on homeless people and Busch-Geertsema (2006) notes several instances of failed prosecutions of homeless people for perceived misdemeanours. Elsewhere, e.g. Sweden and Finland, a similar reluctance to criminalise the homeless is apparent, while in other countries (e.g. Italy, Poland and Lithuania) there are recorded instances of the enlistment of crime prevention agencies in finding solutions (albeit temporary) to the problems of rooflessness caused by the imposition of restricted access to public spaces.

The most frequent reaction to the problems caused for homeless people by the increasing regulation of access to public spaces is that they are either ignored or dealt with through a process which entails the identification of alternative forms of provision such as emergency accommodation. In this sense 'resistance' as used in the title to this section of the report is a misnomer; 'compromise' would perhaps be a more accurate description.

\footnotetext{
7 Volker Busch-Geertsema adds: The German phrase "Hinz und Kunz" can be translated as "Every Tom, Dick and Harry" in British English. But "Kunzt" in the name of the street newspaper plays with the word "Kunst" ("Art"), so "Hinz und Kunzt" also has the implication of "culture for everybody."

8 The scope of this paper has not permitted the deconstruction of the category 'homeless'. In any future study the impact of control measures on homeless people differentiated, for example, by gender and immigrant status would need to be considered.
} 
An example of such 'compromise' is the provision at Gdansk central railway station, following an agreement between homeless NGOs and the railway authorities, of a 'warming-up room' situated close by but outside the station itself; such 'warming-up rooms' can now be found in other stations across Poland. In a similar vein, Elm Larsen (2002) refers to the development in Denmark of 'marginal rooms' (such as special cafés for substance abusers) which nominally include unwanted people who inhabit the local area, but also effectively serve the purpose of excluding them from places where they are deemed undesirable. In another similar development Sahlin (2006: 24) cites the example of the use of mobile out-reach teams which have been formed in Swedish cities to help rough sleepers to find places other than commercial centres in which to spend the night and, previously in this paper, we have noted the example of the establishment of 'Help Centres' in Italian railway stations and the recommissioning of 'Ferrohotels' for homeless accommodation. The difficulty with these measures is that as homeless people are squeezed out from public spaces into temporary accommodation and hostels, they are rarely provided with compensating and systematic support and their problems are consequently mostly exacerbated rather than alleviated. Denied access to public spaces, homeless people are being forced into inadequate sheltered accommodation (which access to public space previously allowed them to avoid) where problems of harsh disciplinary behaviour routines and fear of theft and harassment are all too manifest. Without the provision of adequate alternatives, the regulation of public space is cumulative bad news for homeless people.

As early as 1978 Richard Sennett argued that public space was becoming increasing irrelevant for many urban inhabitants. Later work by Sharon Zukin (1995) and Don Mitchell (2001 \& 2003) reinforced this conclusion. ${ }^{9}$ For all these authors such trends, for a variety of reasons, are considered regrettable (see also Crawford, 1995; Bauman, 2005). A conclusion that can be drawn from their work, however, is that this lack of perceived interest in public space has resulted in a diminished commitment to its preservation, thereby creating a permissive climate in which the process of enclosure, privatisation and surveillance can be freely enacted. The absence of effective opposition to the enclosure of public space can then be interpreted as a reflection of the fact that many residents of and visitors to the cities of Europe (without necessarily recognising the consequences) support the introduction of regulations which limit the access to public space by homeless people. $^{10}$

\section{Conclusions: Understanding regulation}

The surveillance, on the streets and in shelters, of those who are homeless is a distinctive feature of the contemporary city; homeless people are today among the most surveyed and scrutinised of marginal groups (Fopp, 2002; DeVerteuil, 2006). We should, however, be mindful that the homeless have historically been subject to surveillance and regulation: they have been variously contained in workhouses, casual wards, skid rows, hostels and shelters, had their mobility restricted under vagrancy and trespass laws, and their

\footnotetext{
${ }^{9}$ See also: Goheen (1998)

${ }^{10}$ Again, contrasts with events in the USA where many instances of 'resistance' to public space enclosure are on record. See for example Smith (1996)
} 
strategies of survival criminalised. Variability in the degree of regulation and surveillance from one period to another - and indeed from place to place - is explained by changing social relations, political practices and cultural traditions (McCahill, 2002) and by the intensity of the application of regulatory and surveillance techniques. In the present phase of regulation, the surveillance and control of public space is characterised by the emergence of what Ruddick (1996:198) calls 'apodictic' spaces. That is, places of exclusion and privilege in which homeless people are prevented from appropriating space for their own use. In the present phase of regulation, the surveillance of public space with electronic technology aiding and abetting border guards and security patrols - brings the 'calibration and classification' (Fopp, 2002:48) long associated with homeless shelters and hostels to the street, squeezing the spaces in which the homeless can exercise their quotidian functions, denying them space where they have the freedom to 'be' (Waldron, 1993).

In seeking an understanding of why public space is increasingly barred to homeless people, the heightened threat of urban terrorism in the cities of the West must be taken into account. As has been recounted in this paper, the checks and controls introduced at all transport nodes (large and small) are to an extent indicative of these trends (Whent, 1999). The installation of new technology for monitoring and disciplining behaviour can also be seen as part of the same process. However, as Tosi and Petrillo (2006), among others, have pointed out, a concern with the use of public space and the increasing levels of restriction on access and behaviour in those spaces predates the most recent manifestation of urban terrorism in Europe. ${ }^{11}$ Indeed terrorist surveillance only incidentally and indirectly impacts on marginal populations and homeless people. In seeking an understanding of the unprecedented levels of surveillance and concern with how public space is used and by whom, we need to look elsewhere.

Among the possible explanations, the process of privatisation must figure strongly. The shift in 'ownership' of public space from the local state with ostensible social and communal objectives, to private ownership with commercial and profit making objectives, lies at the heart of the trend towards restrictive practices. This process is of course itself but a reflection of wider social developments associated with the emergence of neo-liberal economic and political programmes in all European countries. ${ }^{12}$ Of specific and particular interest here are the programmes for the regeneration of post-industrial European cities, a regeneration process which is increasingly driven by a global agenda. Some of this is neatly captured by Pushpa Arabindoo:

In order to advance the position of the city economically ... political actors are discovering the need for a symbolic assertion - images of a place are crucial for attracting capital investment - and public spaces are turning out to be a crucial ingredient of the new visual repertory that can speak in the name of the city to ... potential investors and transnational actors, as well

\footnotetext{
11 Urban terrorism is distinctive today as a European wide phenomenon but has its precedent in country specific occurrences at various times during the course of $20^{\text {th }}$ century. The most obvious example here is that of IRA attacks on the centres of British cities.

12 Neo-liberalism has of course had an uneven impact on Europe as previous reports from the European Observatory on Homelessness have demonstrated (Doherty et al, 2004 and 2005).
} 
as raise their international profile. (Arabindoo, 2005:2; emphasis added)

Arabindoo's reflections bear a striking similarity to the analysis of Neil Smith who argues that the processes of urban regeneration, so prominent in the cities of Europe and elsewhere, are in effect a generalisation of the process of gentrification first manifest in the cities of the West during the 1960s. In making these arguments Smith coins the concept of the 'revanchist city' whereby capital is attracted back into the city (following desertion during an earlier deindustrialisation phase) to take advantage of what he terms a 'rent-gap' (the difference between the actual rent yielded by a location and the potential rent to be had after redevelopment). In re-colonising the city, capital displaces other incumbent activities and populations including the homeless and other marginal groups (Smith, $1996 \& 2002){ }^{13}$

Making due allowance for poetic licence in the use of the term 'revanchist' and for the problematic application of a concept developed in the USA to the European context (see for example, Uitermark \& Duyvendak, 2005), Smith's ideas have resonance and provide the basis for an understanding of the process of public space regulation in Europe (Meert et al, 2006). He effectively demonstrates that the commodification of space, including public space, is a pivotal process in the regeneration of urban places under conditions of globalisation. Public spaces are being replaced, colonised or neglected in favour of the development of privately owned quasi-public zones where consumption activity is privileged. Privately owned shopping malls and arcades, open only to those with the power to consume, have replaced interactive public places open to all sections of society: in this sense 'commodity commerce' has replaced 'social commerce' (Coleman, 2004). The commodification of space and the associated processes of border control and discipline have thereby further consolidated the division between the 'haves' and the 'have-nots' in society. ${ }^{14}$ The exclusion of undesirables (including homeless people) from newly privatised public space is directly linked with the presentation of 'image' in a highly competitive environment which pervades the global market place as well as national, regional and local market places (Belina and Helms, 2003; Macleod, 2002). Coleman (2004:293) extends this analysis in identifying, in these processes of public space enclosure and exclusion, a 'social control strategy' which seeks 'to hide the [negative] consequences of neo-liberalisation in creating a particular ambience and exclusivity regarding 'public' spaces'; the proclivity of shoppers to consume is thereby untroubled by the close juxtaposition of those who do not have the capacity to consume.

Zygmunt Bauman (1998) in his consideration of trends in modern western society draws a distinction between what he calls 'vagabonds' and 'tourists'. Tourists are those who are embedded in society, articulating its values and behaviour norms in being productively employed and conspicuous consumers. Vagabonds are the opposite, those who are excluded from society in that they are neither workers nor (and for Bauman of equal

\footnotetext{
${ }^{13}$ Indeed one of the features of the 're-defining' of public space which we have not had the opportunity to investigate has been the emergence of gated communities in the centre of European cities; enclave communities segregate elite residential areas from their surroundings and effectively debar access to those who are not deemed to 'belong' (see Webster, 2001 \& Webster et al, 2002)

14 Mike Davies in the context of Los Angles describes this and related processes as leading to the 'militarisation of space', a suggestive concept which nevertheless exaggerates their impact in most European cities (Davis, 1990)
} 
importance) consumers. In our postmodern world of 'liquid modernity' (Bauman, 2000), vagabonds are a redundant population, apparently surplus to the requirements of functioning capitalism. Such a division is of course too starkly drawn in that the wall dividing vagabonds from tourists is permeable, with, for example, immigrants as part of the international reserve army of labour recruited to fuel the burgeoning economies of Europe and elsewhere frequently moving back and forth from one status to another. In the world of European social policy, Bauman's vagabonds are the socially excluded and among these homeless people are perhaps the most socially excluded of all. With the increasing surveillance and regulation of public space a further domain is added to the exclusionary experiences of the homeless. As a facet of social exclusion, homelessness has always been more than a bricks and mortar issue; it is a multifaceted problem involving social relations and personal welfare along side the material conditions of housing circumstances. The regulation and surveillance of public space, however, further restricts the lifeworlds of homeless people, squeezing their autonomy of action, impinging on their personal security and diminishing their claims to dignity and respect.

\section{References}

Arabindoo, P. (2005) Bourgeois Ordering of Public Spaces in Chennai. Paper presented at the BASAS Annual Conference. http://www.staff.brad.ac.uk/akundu/basas/conference05/arabindoo,\%20pushpa.pdf (Accessed 29 November 2007).

Arnold, K.R. (2004) Homelessness, Citizenship and Identity: The uncanniness of late modernity. NY: State University Press.

Bannister, J., and Fyfe, N. (2001) 'Introduction: Fear and the City’. Urban Studies, 38: 807-813.

Bauman, Z. (1998) Globalisation: the human consequences. Oxford: Polity Press.

Bauman, Z. (2000) Liquid Modernity. Oxford: Polity Press.

Bauman, Z. (2005) 'Seeking shelter in Pandora’s box or: fear, security and the city'. City 9(2):161-168.

Belina, B. and Helms, G. (2003) 'Zero Tolerance for the Industrial Past and Other Threats: Policing and Urban Entrepreneurialism in Britain and Germany'. Urban Studies 40(9):1845-1867.

Berg, L. van den, Mingardo, G., Pol, P.M.J. and Speller, C.J.M. (2006), The Safe City; Safety and Urban Development in European Cities. Aldershot: Ashgate.

Blakely, E.J. and Snyder, M.G. (1997) Fortress America: Gated Communities in the United States. Washington, DC: Brookings Institution Press.

Body-Gendrot, S. (2000) The Social Control of Cities? A Comparative Perspective. London: Blackwell.

Brantlinger, P, and Ulin, D. (1993) 'Policing Nomads: Discourse and Social Control in Early Victorian England’. Cultural Critique, 25: 33-63.

Bromley, N. (2006) 'Homelessness and the delusions of property'. Editorial Transactions of the Institute of British Geographers NS 31: 3-5.

Busch-Geertsema, V. (2006) Urban Governance, Homelessness and Exclusion. Homelessness and access 
to space in Germany. National Report for Germany, Working Group 1 European Observatory on Homelessness, FEANTSA, Brussels. http://www.feantsa.org (Accessed 29 November 2007).

Carmona, M., Heath T., Oc, T. and Tiesdell, S. (2003) Public spaces: Urban Spaces. Oxford: Elsevier.

Coleman, R. (2004) 'Reclaiming the Streets: Closed Circuit Television, Neo-liberalism and the Mystification of Social Divisions in Liverpool, UK'. Surveillance \& Society, 2(2/3): 293-309. http://www.surveillance-and-society.org/articles2(2)/liverpool.pdf

Crawford, M (1995) 'Contesting the public realm; struggles over public space in Los Angeles'. Journal of Architectural Education 49(1): 4-9.

Damon, J. (2007) 'For public toilets...' FEANTSA Magazine, Summer 2007: 5-8 http://www.feanrtsa.org (Accessed 29 November 2007).

Davis, M. (1990) City of Quartz: Excavating the Future in Los Angeles. London and New York: Verso.

DeVerteuil, G. (2006) 'The Local State and Homeless Shelters : Beyond Revanchism ?' Cities 23(2): 109120.

Doherty, J, De Decker, P., Busch-Geertsema, V., O’Sullivan, E., Sahlin, I., Tosi, A. and Patari, J. (2004) The Changing Role of the State: The State and the housing markets of Europe. Transnational Report, Working Group 1, European Observatory on Homelessness, FEANTSA, Brussels. http://www.feantsa.org (Accessed 20 November 2007).

Doherty, J., De Decker, P., Busch-Geertsema, V., O’Sullivan, E., Sahlin, I., Tosi, A., Hänninen, S. and Kärkkäinen, S-K. (2005) The Changing Role of the State: Welfare delivery in the neo-liberal era. Transnational Report, Working Group 1, European Observatory on Homelessness, FEANTSA, Brussels. http://www.feantsa.org

Edgar, B, Doherty, J, and Meert, H. (2002) Access to Housing: Homelessness and Vulnerability in Europe. Bristol: The Policy Press.

Eick, V. (2003) 'Social Sorting in the Early 21 st Century Video Surveillance and Governance'. Sarai Reader 03: Shaping Technologies, 321-331. http://www.sarai.net/publications/readers/03-shaping-technologies (Accessed 11 November 2007).

Elden, S. (2003) 'Plague, Panopticon, Police’. Surveillance \& Society 1(3): 240-253.

http://www.surveillance-and-society.org/articles1(3)/ppp.pdf

Elm Larsen, Jørgen (2002) 'Marginale mennesker i marginale rum [Marginal People in Marginal Space]'. In: Järvinen, Margaretha, Elm Larsen, Jørgen \& Mortensen, Nils (Eds.) Det magtfulde møde mellem system og klient [The Powerful Encounter between System and Client]. Århus: Aarhus Universitetsforlag, 148-184.

Ericson, R.V. (1998) Review of 'The Culture of Surveillance: Discipline and Social Control in the United States by William G. Staples'. Social Forces, 76(3):1154-1156.

Farrona, J. R. (2007) 'Violence against homeless people in Spain' FENTSA Magazine, Summer 2007, 6-8. http://www.feantsa.org (Accessed 29 November 2007).

Fopp, R. (2002) 'Increasing the potential for gaze, surveillance and normalisation: the transformation of an Australian policy for people who are homeless'. Surveillance \& Society, 1(1):48-65. http://www.surveillance-and-society.org/articles1/homeless.pdf

Foucault, M. (1977) Discipline and Punish: The birth of the prison. NY: Vintage Press. 
Giannoni, D. (2007) 'The control of Public Space: Brussels South Train Station' FEANTSA Flash, Summer 2007, 9-10. http://www.feantsa.org (Accessed 29 November 2007).

Goheen, P.G.(1998) 'Public space and the geography of the modern city'. Progress in Human Geography 22(4): 479-496.

Gosh, S. (2003) ‘Compassion not Coercion’ CRISIS Briefing Paper, London http://www.crisis.org.uk (Accessed 29 November 2007).

Graham, S. and Marvin, S. (2001) Splintering Urbanism. London: Routledge.

Hall P. (2002) Cities of Tomorrow: An Intellectual History of Urban Planning and Design in the Twentieth Century. Oxford: Blackwell (Third Edition).

Helms, G. (2007) 'Municipal policing meets the new deal: The politics of a city-centre warden project'. European Urban and Regional Studies 14(4): 290-304.

Helten, F. and Fischer, B. (2004) 'Reactive Attention: Video Surveillance in Berlin Shopping Malls.' Surveillance \& Society, 2(2/3): 323-345. http://www.surveillance-and-society.org/articles2(2)/berlin.pdf

Hempel, L. and Töpfer, E. (2002) Urban Eye: Inception Report to the European Commission, 5th Framework Programme, Berlin: Technical University.

Hopper, K. (2003) Reckoning with Homelessness. Ithaca, Cornell University Press.

Johnsen, S. and Fitzpatrick, S. (2007) The impact of enforcement on street users in England. Bristol: The Policy Press.

Karpuskiene, V. (2006) Urban Governance, Homelessness and Exclusion in Lithuania. National Report for Lithuania, Working Group 1, European Observatory on Homelessness, FEANTSA, Brussels. http://www.feantsa.org (Accessed 29 November 2007).

Korhonen, J. (2006) Homelessness and Public Space. National Report for Finland, Working Group 1, European Observatory on Homelessness, FEANTSA, Brussels. http://www.feantsa.org (Accessed 29 November 2007).

Lomell, H. M. (2004) 'Targeting the Unwanted: Video Surveillance and Categorical Exclusion in Oslo, Norway.' Surveillance \& Society 2(2/3): 346-360. http://www.surveillance-and-society.org/articles2(2)/unwanted.pdf

Low, S. and Smith, N. (Eds.) (2006) The Politics of Public Space. Oxford: Routledge.

Lyon, D. (Ed.) (2003) Surveillance as Social Sorting. London: Routledge.

MacLeod G. (2002) 'New Geographies of Power, Exclusion and Injustice: From Urban Entrepreneurialism to a "Revanchist City"? On the Spatial Injustices of Glasgow's Renaissance'. Antipode 34(3) 602617.

McCahill, M. (2002) The Surveillance Web: The Rise of Visual Surveillance in an English City. Cullompton: Willan.

Meert, H. Stuyck, C., José Cabrera, P., Dyb, E., Filipovic, M., Gyori, P., Hradecký, I., Loison, M., and Maas, R. (2006) The Changing Profiles of the Homeless People: conflict, rooflessness and the use of public space. Transnational Report, Working Group 2, European Observatory on Homelessness, FEANTSA, Brussels. http://www.feantsa.org (Accessed 29 November 2007). 
Mitchell, D. (2001) 'Postmodern geographical praxis? Postmodern impulse and the war against homeless people in the "postjustice" city'. In Minca, C. (ed.) Postmodern Geography: Theory and Praxis. Oxford: Blackwell, 57-92.

Mitchell, D. (2003) The Right to the City. London: The Guildford Press.

Monahan, T. (2006a) 'Electronic Fortification in Phoenix: Surveillance Technologies and Social Regulation in Residential Communities.' Urban Affairs Review 42(2): 169-192.

Monahan, T. (2006b) 'Preface': In T. Monahan (ed.) Surveillance and Security: Technological politics and power in everyday life. New York: Routledge, ix-xi.

Müller, C. and Boos, D. (2006) 'Zurich Main Railway Station: A Typology of Public CCTV Systems'. Surveillance \& Society, 2(2/3): 161-176. http://www.surveillance-and-society.org/articles2(2)/zurich.pdf

Nagel, S. (2007) 'Disputes about the prohibition of begging - The example of Hamburg' FEANTSA Magazine Summer 2007, 11-13. http://www.feantsa.org (Accessed 29 November 2007).

Nelkin, D. and Andrews, L. (2003) 'Surveillance creep in the genetic age' in David Lyon (ed.) Surveillance as social sorting. London: Routledge, 94-110.

Norris, C. (2003) 'From personal to digital: CCTV, the Panopticon, and the technological mediation of suspicion and social control' in David Lyon (ed.) Surveillance as Social Sorting. London: Routledge, 249-181.

Norris, C., McCahill, M. and Wood, D. (2004) 'Editorial: The Growth of CCTV: a global perspective on the international diffusion of video surveillance in publicly accessible space'. Surveillance \& Society 2(2/3): 110-135. http://www.surveillance-and-society.org/articles2(2)/editorial.pdf

O’Sullivan, E. (2006) Homelessness and public order in Ireland. National Report for Ireland, Working Group 1, European Observatory on Homelessness, FEANTSA, Brussels. http://www.feantsa.org (Accessed 29 November 2007).

O’Sullivan, E. (2007) 'Criminalising People who are Homeless?' FEANTSA Magazine, Summer 2007, 11 13. http://www.feantsa.org (Accessed 29 November 2007).

Oc, T. and Tiesdell, S. (1997) Safer City Centres; Reviving the Public Realm London: Paul Chapman.

Ruddick, S. M. (1996) Young and Homeless in Hollywood: Mapping social identities. London: Routledge.

Sætnan, A R., Lomell, H. M. and Wiecek, C. (2004) 'Controlling CCTV in Public Spaces: Is Privacy the (Only) Issue? Reflections on Norwegian and Danish observations'. Surveillance \& Society 2(2/3): 396-414. http://www.surveillance-and-society.org/articles2(2)/controlling.pdf

Sahlin, I. (2006) Urban definitions of places and behaviour. National Report for Sweden, Working Group 1, European Observatory on Homelessness, FEANTSA, Brussels. http://www.feantsa.org (Accessed 29 November 2007).

Sennett, R. (1978) The Fall of Public Man: On the Social Psychology of Capitalism. New York: Vintage.

Seymour, M. and Costello, L, (2005) 'Profile and progression routes of homeless persons before the court and in custody'. Government of Ireland, Dublin. http://www.pws.ie/Clients/PWS/PWSweb.nsf/HomelessARTWORK.pdf (Accessed 29 November 2007).

Smith, N. (1996) The New Urban Frontier: Gentrification and the Revanchist City. London, Routledge. 
Smith, N. (2002) 'New Globalism, New Urbanism: Gentrification as a new global strategy'. Antipode 34(3): 434-457.

Staples, W.G. (1997) The Culture of Surveillance: Discipline and Social Control in the United States. New York: St. Martin's Press.

Töpfer, E., Hempel, L. and Cameron, H. (2003) Watching the Bear: Networks and islands of visual surveillance in Berlin. Urbaneye Working Paper No. 8. Centre for Technology and Society, Technical University of Berlin. http://www.urbaneye.net/results/results.htm (Accessed 29 November 2007).

Tosi, A. and Petrillo, A. (2006) Urban Governance, homelessness and exclusion in Italy. National Report for Italy, Working Group 1, European Observatory on Homelessness, FEANTSA, Brussels. http://www.feantsa.org (Accessed 29 November 2007).

Uitermark, J., Duyvendak, J. W. (2005) 'Civilising the City; Revanchist Urbanism in Rotterdam'. ASSR Working Paper 05/05 http://www2.fmg.uva.nl/assr/workingpapers/documents/ASSR-WP0505.pdf (Accessed 29 November 2007).

Urbaneye, (2004) On the Threshold to Urban Panopticon? Analysing the Employment of CCTV in European Cities and Assessing its Social and Political Impacts. Final Report to the European Union, Technical University of Berlin. http://www.urbaneye.net/results/ue wp15.pdf (Accessed 29 November 2007)

Wacquant, L. (1999) 'US Exports Zero Tolerance: Penal 'common sense' comes to Europe’. Le Monde Diplomatique / The Guardian Weekly, April 1999, 10-11. [Translated by Tarik Wareh].

Wacquant, L. (2001) 'The penalisation of poverty and the rise of neo-liberalism'. European Journal of Criminal Policy and Research 9(4): 401-412

Waldron, J. (1993) 'Homelessness and the issue of freedom'. In Waldron, J. (ed.) Liberal Rights: Collected papers, 1981-91. Cambridge: CUP, 36-61.

Webster, C. (2001) ‘Gated Cities of Tomorrow.’ Town Planning Review 72: 149-170.

Webster, C., Glaze, G. and Frantz, K. (2002) 'The global spread of gated communities.' Environment and Planning B: Planning and Design, Guest Editorial, 29: 315-320.

Westminster Council (2003) 'Begging Strategy'

http://www.westminster.gov.uk/communityandliving/communitysafety/begging (Accessed 29 November 2007).

Whent, P. (1999) 'Control of Public Spaces.' APTA Rapid Transit Conference Proceedings, Washington D.C. http://www.apta.com/research/info/briefings/documents/whent.pdf (Accessed 29 November 2007).

Wygnańska, J. (2006) Homeless and access to space. National Report for Poland, Working Group 1, European Observatory on Homelessness, FEANTSA, Brussels. http://www.feantsa.org (Accessed 29 November 2007).

Zuidam, P and Pols, G. (2007) 'On criminalisation of homelessness and people who are homeless in Rotterdam' FEANTSA Flash, Summer 2007, 14-16. http://www.feantsa.org (Accessed 29 November 2007).

Zukin, S. (1995) The Cultures of Cities. Oxford, Blackwell. 